\title{
OS ADUBOS .. MINERAIS NITROGENADOS NA CULTURA DO ALGODOEIRO *
}

\author{
CARIVALDO GODOY JUNIOR
}

Escola S. Agricultura "Luiz de Queiroz". U. S. P.

INDICE

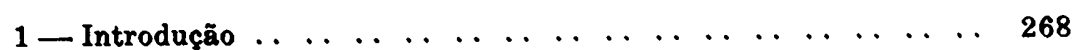

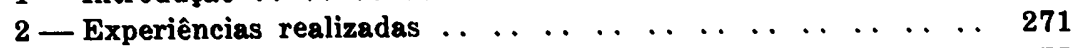

3- Resumo e Conclusões . . . . . . . . . . . . . . . . . . 275

4- Bibliografia . . $\ldots \ldots \ldots \ldots \ldots$

- Trabalho da 4a. Cadeira (Agricultura Especial e Genética Aplicada) 


\section{1 - INTRODUÇÃO}

\section{1 - Exigência do algodoeiro em relação ao nitrogênio}

O algodoeiro é considerado entre as grandes culturas como uma das plantas mais exigentes sob o ponto de vista químico.

Os números indicados abaixo, obtidos por Bolliger, citação de D'UTRA (3), se referem às quantidades calculadas de elementos encontrados nas plantas do algodoeiro e correspondentes a uma prcdução estimada em 240 arrobas por hectare.

$\begin{array}{lr}\mathrm{N} & 196,699 \mathrm{~kg} \\ \mathrm{~K} 2 \mathrm{O} & 149,667 \mathrm{~kg} \\ \mathrm{P} 2 \mathrm{O} 5 & 41,162 \mathrm{~kg} \\ \mathrm{CaO} & 162,953 \mathrm{~kg}\end{array}$

Esses números têm apenas um valor relativo e se prestam mais para mostrar a posição de cada elemento quanto às exigências do algodoeiro. Sob êste ponto de vista, podemos observar que o nitrogênio se destaca entre os demais, de maneira a não deixar dúvidas.

Encontra-se o nitrogênio distribuido em tôdas as partes do algodoeiro e segundo o trabalho referido acima, nas seguintes porcentagens em relação à substância úmida :

$\begin{array}{ll}\text { Raizes } & 0,185 \% \\ \text { Galhos } & 0,199 \% \\ \text { Fôlhas } & 0,935 \% \\ \text { Capsulas } & 1,824 \% \\ \text { Grãos } & 3,597 \% \\ \text { Fibras } & 0,773 \%\end{array}$

E' evidente aqui a maior concentração dêsse elemento nos órgãos de reprodução o que nos leva a concluir que a sua necessidade se faz sentir mais no período de floração. De fato, segundo White, citação de BROWN (2), é a seguinte a distribuição porcento das exigências nos vários períodos do ciclo vegetativo : 
1.o) Da germinação ao início de formação de botões florais

2.o) Do início de formação de botões ao início de florescimento $32 \%$

3.o) Do início de florescimento ao início da deiscência dos frutos $18 \%$

4.o) Do início da deiscência ao final do ciclo

$16 \%$

A duração provável dêsses períodos numa planta de algodoeiro cultivada em nosso meio é a seguinte : primeiro período, 40 dias; segundo período, 20 dias; terceiro período, 60 dias; quarto período, 90 dias. Se procurarmos saber as necessidades diárias, dividindo aquelas porcentagens pelo número de dias dos respectivos períodos teremos, respectivamente $0,85 \%, 1,60 \%$, $0,30 \%$ e $0,17 \%$.

Considerando ainda que entre nós a fase mais intensa de floração do algodoeiro se estende por aproximadamente 60 dias, correspondendo aos meses de janeiro e fevereiro para as plantas nascidas no início de novembro, podemos concluir que a fase de máxima necessidade em nitrogênio vai até, mais ou menos, o $120^{\circ}$. dia após a germinação. Contudo não devemos nos esquecer de que embora em menores quantidades, mesmo no período que vai da abertura dos capulhos até o final do ciclo, o algodoeiro continua a assimilar o nitrogênio.

A assimilação do nitrogênio pelo algodoeiro pode ser controlada fàcilmente pela reação da difenilamina com o nitrato acumulado no pecíolo das fôlhas adjacentes ao caule. (6).

\section{2 - Esgotamento produzido pelo algodoeiro em relação ao nitrogênio}

Censiderando que no Estado de São Paulo, os restos da cultura algodoeira devem ser arrancados e queimados em virtude da broca e da lagarta rosada, com consequente perda total do nitrogênio e, em regra geral, os caroços ou sua torta não voltam para o campo de cultura, somos levados a concluir que o esgotamento em relação ao nitrogênio se confunde aqui com a exigência.

Portanto, mais que em qualquer outra cultura, o problema das adubações nitrogenadas, exige dos técnicos, uma atenção toda especial.

Se fosse possível fornecer ao solo, sob forma orgânica, todo o nitrogênio necessário, seria a melhor solução, pois que dêsse modo êle seria cedido lentamente, com menor probabilidade 
de perdas por lavagens. Entretanto, não sendo possível, somos obrigados a recorrer aos adubos minerais nitrogenados.

\section{3 - Os adubos minerais nitrogenados}

Dos adubos minerais nitrogenados encontrados no comércio, os mais difundidos na prática agrícola, são o salitre do Chile e o sulfato de amônio.

$O$ primeiro se caracteriza por ser um adubo prontamente assimilável, de reação alcalina, fàcilmente lavável; deve ser aplicado quando necessário sendo que em doses elevadas prolonga o período de crescimento e favorece a produção de folhagem em prejuizo da produção de semente. (4)

Experiências na Estação Experimental de Agricultura de Mississippi (U.S.A.) indicam que doses maiores que 200 libras por "acre" não determinam aumento de produção, como mostram os dados abaixo: (1)

\begin{tabular}{l|c}
\hline Tratamento & $\begin{array}{c}\text { Algodão em } \\
\text { caroço ls/acre } \\
\text { Média de 6 anos }\end{array}$ \\
\hline Testemunha & 222 \\
100 ls/acre & 326 \\
150 ls/acre & 367 \\
200 ls/acre & 423 \\
250 ls/acre & 420 \\
300 ls/acre & 432 \\
\hline
\end{tabular}

O sulfato de amônio, depois do salitre, é o adubo nitrogenado mais ràpidamente ativo (4) e é menos sujeito à lixiviação porque o solo tem um certo poder de adsorção para o radical amônio; é de reação ácida.

Para Nelson e Ware, citação de WINSTON NEELY (9) o nitrogênio determinou um aumento no tamanho das capsulas e no índice de semente, e uma diminuição na porcentagem e no índice de fibra. 


\section{4 - Momento de aplicação do salitre do Chile e do sulfato de amônio}

Em consequência da solubilidade e da lavagem a que estão sujeitos êstes dois adubos, surge a questão do melhor momento de sua aplicação tendo em vista ainda as necessidades do algodoeiro em relação ao nitrogênio nos diferentes períodos de desenvolvimento.

A opinião predominante nos Estados Unidos da America do Norte é que o nitrato de sódio e os fertilizantes fàcilmente solúveis devem ser aplicados em cobertura ou, então, uma parte no plantio e o resto por ocasião do primeiro desbaste ou do aparecimento dos botōes florais. (2)

Conforme citação de MALAVOLTA (7), Schreiner e Skinner (1934), Williamson e Funchess (1923) e Bledsoe (1929) obtiveram com a aplicação de salitre e sulfato de amônio no momento de plantio resultados tão bons como quando distribuidos em cobertura.

AUNON (1) observou um atrazo na germinação do algodoeiro num ensaio em que aplicou salitre no momento da semeadura.

BROWN (2) chama a atenção para o fato de que a aplicação do salitre antes do plantio, além do perigo de lavagem, pode favorecer o desenvolvimento das ervas más, com prejuizos da cultura.

MENDES (8) encontrou resultados positivos para o salitre quando aplicado tardiamente (54 ou 90 dias após a germinação); contudo, se manifestou pessimista em relação ao emprêgo do salitre ou do sulfato de amônio na cultura do algodoeiro.

\section{2 - EXPERIENCIAS REALIZADAS}

2.1 - Experiência no ano agrícola 1950-51

\subsection{1 - Método e material}

Este capítulo pode ser resumido nos seguintes itens:

a) Solo - A experiência foi realizada numa parcela de terra roxa, já bastante cultivada, da Secção Técnica anexa à cadeira de Agricultura Especial, da Escola S. A. "Luiz 
de Queiroz". A referida parcela havia recebido nos dois anos anteriores uma bôa adubação potássica, sob a forma de cinza e outra fosfatada, sob a forma de serranafosfato.

b) Variedade - Foram usadas sementes da variedade "Express" obtidas em nosso próprio campo de cultura e expurgadas no vácuo pelo sulfeto de carbono.

c) Tratamentos - Ao lado da testemunha que recebeu o tratamento básico acima citado, experimentámos o salitre e o sulfato de amônio, ambos na base de $150 \mathrm{~kg}$ por hectare , o que corresponde a $1.500 \mathrm{~kg}$ por canteiro de $5,0 \mathrm{x}$ $20,0 \mathrm{~m}$, que foi o usado na experiência. Esta última quantidade de adubo foi ministrada em 3 doses de $0,500 \mathrm{~kg}$, aplicadas no $45^{\circ}$., $90^{\circ}$. e $135^{\circ}$. dia, após a germinação.

d) Repetições - Foram usadas em número de oito, distribuidas ao acaso no terreno.

e) Resumo do decorrer do ano agrícola - Ano favorável para o crescimento, regular para a floração e bom para a maturação e deiscência dos frutos.

\subsection{2 - Resultados obtidos e análise estatística}

Os resultados obtidos foram os do quadro n. 1.

Quadro n. 1 - Produção de algodão em caroço

\begin{tabular}{|c|c|c|c|c|}
\hline Tratamento & $\begin{array}{l}\text { Média obtida } \\
\text { kgs/canteiro } \\
(100 \mathrm{~m} 2)\end{array}$ & $\begin{array}{l}\text { Calculada } \\
\text { arroba/ha }\end{array}$ & $\begin{array}{c}\text { Calculada } \\
\text { arroba/alq. }\end{array}$ & $\begin{array}{c}\text { Ns. propror- } \\
\text { cionais }\end{array}$ \\
\hline $\begin{array}{l}\text { Testemunha } \\
\text { Salitre do Chile } \\
\text { Sulf. de amônio }\end{array}$ & $\begin{array}{l}17,233 \\
19,861 \\
18,941\end{array}$ & $\begin{array}{l}114,8 \\
132,4 \\
126,2\end{array}$ & $\begin{array}{l}277,8 \\
320,4 \\
305,4\end{array}$ & $\begin{array}{l}100 \\
115 \\
109\end{array}$ \\
\hline
\end{tabular}

$O$ valor de " $F$ " calculado foi 5,23 sendo que na tabela o encontrámos igual a 6,51 para $1 \%$ e 3,74 para $5 \%$. Nossa experiência foi portanto significante para $5 \%$. 
Uma diferença entre médias de canteiro maior que $1,766 \mathrm{~kg}$ é significante, o que nos leva a concluir que no ano agrícola estudado apenas o salitre produziu resultado significante pois rendeu $2.628 \mathrm{~kg}$ a mais que a testemunha. Pouco faltou para que a diferença entre o sulfato de amônio e a testemunha $(1,708 \mathrm{~kg})$ fosse significante.

2.2 - Experiência realizada no ano agrícola 1951-52

2.2.1 - Método e material

O método e o material usados neste ano agrícola foram os mesmos observados no anterior, razão pela qual apenas vamos esclarecer alguns pontos.

a) Solo - A experiência foi instalada na mesma parcela de terra roxa, sendo que os restos da cultura anterior foram arrancados e incinerados fora.

b) Variedade - Usámos as sementes da variedade "Express" cultivada no ano anterior. $O$ algodão foi beneficiado separadamente em máquina particular e as sementes expurgadas no vácuo, pelo sulfeto de carbono.

c) Tratamentos - Os mesmos.

d) Repetições - Idem.

e) Resumo do decorrer do ano agrícola - A falta de chuvas prejudicou o primeiro desenvolvimento da cultura e uma chuva de granizo em 31-12-52 prejudicou um tanto a produção.

\subsection{2 - Resultados obtidos e análise estatística}

Os resultados obtidos foram os do quadro n. 2.

Quadro n. 2 - Produção de algodão em caroço

\begin{tabular}{l|c|c|c|c}
\hline Tratamento & $\begin{array}{c}\text { Média obtida } \\
\text { kgs/canteiro } \\
\text { (100m2) }\end{array}$ & $\begin{array}{c}\text { Calculada } \\
\text { arroba/ha }\end{array}$ & $\begin{array}{c}\text { Calculada } \\
\text { arroba/alq. }\end{array}$ & $\begin{array}{c}\text { Ns. propror- } \\
\text { cionais }\end{array}$ \\
\hline Testemunha & 16,123 & 107,4 & 259,9 & 100 \\
Salitre do Chile & 19,701 & 131,3 & 317,7 & 122 \\
Sulf. de amônio & 20,127 & 134,1 & 324,5 & 124 \\
\hline
\end{tabular}


O valor de " $F$ " calculado foi 11,18 sendo que na tabela 0 encontrámos igual a 6,51 para $1 \%$ e 3,74 para $5 \%$. Nossa experiência foi, pois, significante para $1 \%$.

Uma diferença entre médias de canteiro maior que 1,992 $\mathrm{kg}$ é significante, o que nos leva a concluir que no ano agrícola 1951-52, o salitre do Chile e o sulfato de amônio produziram resultados significantes com $3,578 \mathrm{~kg}$ e $4,004 \mathrm{~kg}$, respectivamente, a mais que a testemunha. Não houve, contudo diferença entre os dois adubos.

\section{3 - Análise estatística do biênio 1950-51 a 1951-52}

Os resultados obtidos no biênio estão resumidos no quadro n. 3.

Quadro n. 3 - Produção de algodão em caroço no biênio

\begin{tabular}{|c|c|c|c|c|}
\hline Tratamento & $\begin{array}{l}\text { Total em kgs } \\
\text { (16 canteiros) }\end{array}$ & $\begin{array}{l}\text { Calculada } \\
\text { arroba/ha }\end{array}$ & $\begin{array}{l}\text { Calculada } \\
\text { arroba/alq. }\end{array}$ & $\begin{array}{l}\text { Ne. propror- } \\
\text { ciona is }\end{array}$ \\
\hline $\begin{array}{l}\text { Testemunha } \\
\text { Salitre do Chile } \\
\text { Sulf. de amônio }\end{array}$ & $\begin{array}{l}266,86 \\
316,50 \\
312,55\end{array}$ & $\begin{array}{l}111,1 \\
131,8 \\
130,2\end{array}$ & $\begin{array}{l}268,8 \\
318,9 \\
315,0\end{array}$ & $\begin{array}{l}100 \\
118 \\
117 \\
\end{array}$ \\
\hline
\end{tabular}

"F" calculado foi igual a 15,40 enquanto que na tabela achámos 5,45 para $1 \%$ e 3,34 para $5 \%$. Portanto, no conjunto dos 2 anos, a nossa experiência se mostrou significante para $1 \%$.

Uma diferença entre totais de tratamento maior que 20,336 $\mathrm{kg}$ é significante. Logo :

a) O salitre do Chile, quando aplicado em 3 doses de $0,500 \mathrm{~kg}$ no $45^{\circ}, 90^{\circ}$ e $135^{\circ}$ dia após a germinação, influiu de modo significante em relação à testemunha, pois produziu $49,64 \mathrm{~kg}(316,50-266,86)$ a mais, o que corresponde a um aumento de $18 \%$.

b) O sulfato de amônio também influiu de modo significante em relação à testemunha, pois produziu $45,69 \mathrm{~kg}(312,55$ $-266,86$ ) a mais, o que corresponde a um aumento de $17 \%$. 
c) Não houve diferença significante entre os dois adubos estudados.

Concluimos ainda da análise estatística que não houve diferença de produção significante entre os dois anos estudados.

\section{3 - RESUMO E CONCLUSÕES}

Estudámos a aplicação do salitre do. Chile e do sulfato de amônio, em cobertura, em 3 doses de $0,500 \mathrm{~kg}$, no $45^{\circ}$., $90^{\circ}$. e $135^{\circ}$. dia após a germinação, nos anos agrícolas de 1950-51 e 1951-52.

Em 1950-51 o emprêgo do salitre foi significante, pouco faltando ao sulfato de amônio para o ser.

Em 1951-52, bem como no biênio, ambos os adubos produziram resultados significantes.

O aumento de produção foi de $18 \%$ e de $17 \%$ respectivamente, para o salitre e o sulfato de amônio.

\section{4 - BIBLIOGRAFIA}

1 AUNON, Pedro Cruz (1949). El Algodonero en Espana. Madrid. Espanha.

2. BROWN, Harry Bates (1938). Cotton. Mc Graw-Hill Book Company, inc. New York. U.S.A.

3. D'UTRA, Gustavo R. P. (1916). Cultura do Algodoeiro (2a. edição). Casa Duprat. São Paulo. Brasil.

4. GARDNER, W. (1948). Fertilizers and Soil Improvers. Technical press. London. England.

5. GRANER, E. A. (1952). Como Aprender Estatística. Edições Melhoramentos. São Paulo. Brasil. 
6. KRANTZ, Bert A., W. L. Nelson e L. F. Burkhart (1948). Diagnostic Techiniques for Soils and Crops. Plant-tissue Test as a Tool in Agronomic Research. The American Potash Institute. Washington. U. S. A.

7. MALAVOLTA, Euripedes (sem data). A aplicação dos Adubos Comerciais. (folheto).

8. MENDES, Carlos Teixeira (1948). Adubações Azotadas. Revista de Agricultura. 23: 271-289.

9. NEELY, J. Winston (1947). Direccion de Algodón (boletim mensal). Ns. 149-150: 315-324. Versão castelhana de “Technical Bulletin n. 28, Mississippi Agricultural Experiment Station", December, 1940. 